\title{
SPOSOBY ZDOBYWANIA I PRZETWARZANIA INFORMACJI W UJĘCIU NEUROBIOLOGICZNYM I KULTUROWYM. PRZYKLAD STUDENTÓW CHIŃSKICH UCZĄCYCH SIĘ JĘZYKA POLSKIEGO
}

\begin{abstract}
Słowa kluczowe: nauczanie języka polskiego jako obcego, strategie prawopółkulowe, styl poznawczy, język chiński

Streszczenie. Niniejszy artykuł podejmuje kwestie wpływu uwarunkowań neurobiologicznych oraz czynników kulturowych na sposoby zdobywania i przetwarzania informacji, co z kolei determinuje wybór sposobów uczenia się. W artykule omówiona została kwestia preferencji półkulowych w kontekście edukacyjnym. Podstawą wywodu oraz przyczynkiem do podjęcia badań sondażowych jest hipoteza, że osoby wychowane w kulturze chińskiej i posługujące się językiem mandaryńskim jako ojczystym częściej stosują strategie prawopółkulowe niż przedstawiciele kultury Zachodu, których język ojczysty różni się znacząco od mandaryńskiego w zakresie systemu fonetyczno-fonologicznego, leksyki, pisma oraz gramatyki.

W części badawczej zaprezentowano wyniki obserwacji i badań sondażowych przeprowadzonych wśród słuchaczy studiów polonistycznych pochodzących z Chin. Podstawowy cel obserwacji stanowiła identyfikacja stosowanych przez nich metod i technik uczenia się. Wnioski płynące z badań zostały zinterpretowane w oparciu o czynniki kulturowe (język ojczysty i praktyki społeczne), które w sposób szczególny mogą wpływać na wybór strategii prawopółkulowych w procesie uczenia się języka obcego.
\end{abstract}

\section{WPROWADZENIE}

Efektywność uczenia się zależna jest od wielu czynników. Wśród zmiennych wpływających na sposoby zdobywania wiedzy wylicza się szereg uwarunkowań związanych $\mathrm{z}$ naturalnym potencjałem uczącego się, czynniki

*adriana.prizel-kania@uj.edu.pl, Uniwersytet Jagielloński, Wydział Polonistyki, Instytut Glottodydaktyki Polonistycznej, ul. Grodzka 64, 31-004 Kraków. 
osobowościowe oraz wpływy kulturowe. Roli zmiennych indywidualnych oraz czynników kulturowych w rozwoju poznawczym człowieka poświęcono wiele prac z zakresu różnych dziedzin nauki: psychologii (rozwojowej i międzykulturowej), neurobiologii, etnolingwistyki, logopedii oraz dydaktyki. Trwająca od czasu J. Locke'a i J. J. Rousseau dyskusja między empirystami i natywistami zmienia swoje oblicze wraz z rozwojem nauki i w świetle wyników najnowszych badań. Odpowiedzi na filozoficzne w gruncie rzeczy pytanie o to, co decyduje o naszym rozwoju i sposobie funkcjonowania (natura i wyposażenie genetyczne czy środowisko, w którym żyjemy) dostarcza Teoria Podwójnego Dziedziczenia (Durham 1991). Podkreśla ona, że rozwój człowieka zależy zarówno od dziedziczenia biologicznego, jak i procesów kulturowego uczenia się i internalizacji, za pomocą których rozwijające się jednostki zaczynają obserwować (a potem przyswajają, traktując jako własne) fenomeny typowe dla członków danej społeczności. Większość kompetencji poznawczych należy zatem uznać za wypadkową wielu procesów historycznych i ontogenetycznych, pamiętając jednakowoż, że możliwości uczenia się są uruchamiane przez biologicznie odziedziczoną zdolność poznawczą (Tomasello 2002, s. 22-23).

Badania prowadzone na gruncie psychologii międzykulturowej dowodzą, że czynniki środowiskowe wpływają na takie procesy, jak: sposoby kategoryzacji, rozwiązywanie problemów, udział pamięci w przetwarzaniu informacji oraz style uczenia się (Boski 2010, Markus, Kitayama 1993, Matsumoto, Juang 2007, Nisbett 2015).

W niniejszym artykule, w koniecznym skrócie, przedstawione zostaną badania na temat sposobu przetwarzania informacji przez mózg (podstawy biologiczne) oraz czynniki kulturowe (specyfika języka mandaryńskiego i wybrane aspekty życia społecznego) wpływające na praktyki edukacyjne studentów chińskich uczących się języka polskiego.

Podstawową myśl stanowi hipoteza o preferencji prawopółkulowych sposobów przetwarzania informacji przez tę grupę studentów. Wybór strategii prawopółkulowych ma charakter nieświadomy i może być wynikiem wpływów kulturowych, przyzwyczajeń edukacyjnych, a także samej specyfiki języka chińskiego, którego użycie przez studentów chińskich wymaga zwiększonej aktywności prawej strony mózgu. Na tej podstawie można sformułować dwa zasadnicze pytania badawcze: czym charakteryzują się sposoby przetwarzania informacji u studentów chińskich oraz w jaki sposób może to wpływać na proces uczenia się języka polskiego. Odpowiedzi na pierwsze z nich dostarczają badania przeprowadzone przez naukowców specjalizujących się w tej dziedzinie, na drugie - opisane w niniejszym artykule badanie sondażowe, będące wstępem do badań właściwych. 


\section{PRAWO- I LEWOPÓŁKULOWE SPOSOBY PRZETWARZANIA INFORMACJI}

Mózg ludzki, pomimo że zbudowany jest z dwóch wyglądających niemalże identycznie części, nie jest strukturą w pełni symetryczną. Prawa i lewa część mózgu różnią się zarówno pod względem budowy anatomicznej, jak i sprawowanych przez nie funkcji. Pierwszych informacji na ten temat dostarczają przeprowadzone w XIX wieku badania osób, u których nastąpiło uszkodzenie różnych struktur kory mózgowej. Ustalono wówczas, że ze względu na lokalizację ośrodków ekspresji i recepcji mowy w lewym płacie czołowym (Pole Broca) i w lewym płacie skroniowym (ośrodek Wernickego), to właśnie lewa część mózgu odgrywa zasadniczą rolę w przetwarzaniu informacji językowych (Berko Gleason, Bernstein Ratner 2005, s. 68-70). Szczególne miejsce umiejętności komunikacyjnych w ogólnym rozwoju człowieka i jednoznaczne powiązanie funkcji językowych z lewą półkulą utrwaliło pogląd, że to właśnie lewa część mózgowia jest dominująca dla wszelkich funkcji psychicznych, a prawa jest podporządkowana jej działaniom (Grabowska 2012, s. 453).

Szczególnie istotne dla zweryfikowania tych poglądów stały się badania przeprowadzone na pacjentach po komisurotomii ${ }^{1}$, czyli operacji przecięcia spoidła wielkiego, które łączy obie półkule mózgu. Główną funkcją spoidła wielkiego jest umożliwienie przepływu impulsów elektrycznych z jednej strony mózgu do drugiej. Przecięcie tej wiązki włókien nerwowych pozwoliło zatem na sprawdzenie, w jaki sposób funkcjonuje każda $\mathrm{z}$ półkul mózgowych w sytuacji braku możliwości przepływu bodźców pomiędzy nimi. Pierwszego zabiegu komisurotomii dokonał R. Sperry, rozpoczynając tym samym nowe możliwości badawcze nad odmiennością w specjalizacjach półkul mózgowych. Badania te pozwoliły wykazać aktywny udział prawej półkuli przy przetwarzaniu danych językowych oraz potwierdziły, że asymetria czynnościowa mózgu nie dotyczy jedynie funkcji mowy. R. Sperry udowodnił, że każda z półkul posiada zakres działań, w których przejawia większą sprawność. Prawa półkula opracowuje bodźce poprzez ich syntezę, lewa analizuje części składowe linearnie, koncentrując się na szczegółach (Szaląg 2012, s. 493-495). Jak pisze A. Grabowska, „teoria ta stanowiła całkowity przewrót $\mathrm{w}$ sposobie myślenia o asymetrii półkulowej, zakładała bowiem, że półkule nie specjalizują się w analizie konkretnego rodzaju materiału, lecz różnią się sposobem analizowania. W zależności od tego, jaki typ analizy może prowadzić do lepszych wyników w danym zadaniu, uzyskuje się albo przewagę lewej, albo prawej półkuli” (2012, s. 455). Ostatnie zdanie należy uznać za

${ }^{1}$ Operację przecięcia spoidła wielkiego wykonuje się u pacjentów cierpiących na niepoddającą się leczeniu farmakologicznemu postać epilepsji w celu zmniejszenia obszarów kory mózgowej podczas patologicznych wyładowań elektrycznych (Grabowska 2012, s. 445). 
kluczowe w opisie sposobu pracy mózgu. Nie można bowiem zamknąć wszystkich aktywności w prostej dychotomii - analiza versus synteza. Prowadziłoby to bowiem do zbyt dużego uproszczenia istoty asymetrii półkulowej. W wykonywanie różnego rodzaju zadań zaangażowane są obie półkule, ponieważ ich sprawna współpraca daje najlepsze efekty. Mózg jest systemem dynamicznym, w którym każda z półkul angażowana jest do wykonywania określonego rodzaju działań w sposób zmienny - pobudzenie po prawej lub lewej stronie kory mózgowej może się zmieniać z sekundy na sekundę. Wszystkie działania wykonywane są komplementarnie i w ciągłej współpracy obu stron mózgu (Budohowska, Grabowska 1994, Cieszyńska-Rożek 2013, Gazzaniga 2011, Grabowska 2012, Panasiuk 2017). Zróżnicowanie funkcjonalne półkul mózgowych należy zatem opisywać wielopoziomowo, biorąc pod uwagę sposób przetwarzania informacji, preferencje co do materiału wyjściowego i zróżnicowanie w obrębie opracowywania poszczególnych jego składowych oraz osobniczą zmienność będącą wynikiem różnic strukturalnych i rozwojowych (w tym działania czynników środowiskowych, do których zaliczyć należy także wpływy kulturowe). Znaczący przyrost wiedzy na temat czynnościowej asymetrii mózgu stał się możliwy dzięki badaniom prowadzonym za pomocą funkcjonalnego rezonansu magnetycznego. Technika ta pozwala na obrazowanie i rejestrowanie zmian w aktywności różnych części mózgu podczas wykonywania określonych zadań. Dzięki rozwojowi technik fRMI możliwe stało się tworzenie trójwymiarowych obrazów pracującego mózgu i obserwacja na ekranie komputera aktywności wybranych obszarów kory mózgowej, co pozwoliło na dookreślenie specjalizacji prawej i lewej półkuli.

$\mathrm{W}$ zakresie funkcji psychicznych prawa półkula posiada przewagę $\mathrm{w}$ ocenie i analizie przestrzeni oraz przetwarzaniu emocji. Jej sposób działania charakteryzuje symultaniczne opracowywanie wszystkich bodźców składających się na obraz ogólny, rozpoznawanie i identyfikowanie w oparciu o podobieństwa oraz integracja informacji płynących ze wszystkich zmysłów. Prawa część mózgu zaangażowana jest także w działania muzyczne - rozpoznaje i kontroluje dźwięki, rytm, tony. Przetwarza również znaki ikoniczne (w tym piktogramy), ocenia odległości, powierzchnię, głębię oraz tworzy wyobrażenia wizualne. Aktywność tej części mózgu jest również niezwykle istotna przy zapamiętywaniu i opracowywaniu materiału językowego. Do zadań prawej półkuli w tym zakresie należy analiza warstwy prozodycznej mowy (melodia języka, akcent, rytm, tonacja), rozumienie wyrażeń dźwiękonaśladowczych oraz wnioskowanie z kontekstu i konsytuacji, dzięki czemu możliwa staje się interpretacja metafor oraz rozumienie treści wyrażanych nie wprost (ironii, sarkazmu, gier słownych, dowcipów i związków frazeologicznych) (Cieszyńska-Rożek 2013, s. 40-41). Jak piszą W. Budohowska i A. Grabowska, prawa półkula „lepiej rozumie język mówiony” (1994, s. 62). Zwiększoną aktywność prawej półkuli obserwuje się także przy pamięciowym opanowywaniu tekstów - wierszy, piosenek, ale również krótszych 
i dłuższych tekstów ciągłych. Dowiedziono również udział prawej półkuli w rozpoznawaniu rzeczowników prezentowanych w formie mianownika i kojarzenia ich $\mathrm{z}$ desygnatem.

W lewej półkuli zlateralizowane są funkcje językowe pozwalające na nadawanie i odbiór komunikatów. Ta strona mózgu opracowuje bodźce sekwencyjnie poprzez linearną analizę kolejnych elementów. To tutaj dochodzi do identyfikacji różnic (także pomiędzy fonemami, literami i wyrazami) i przetwarzania reguł (w tym reguł gramatycznych) (Szeląg 2012, s. 495) ${ }^{2}$. Lewa półkula odpowiada za rozumienie zjawisk połączonych łańcuchem zdarzeń i myślenie przyczynowo-skutkowe. Często przypisuje się jej także zdolność logicznego myślenia, które opiera się na analizie przesłanek, wyciąganiu wniosków i podejmowaniu na tej podstawie odpowiedniej decyzji (Cieszyńska-Rożek 2013, s. $41-43)$.

Opisując i analizując sposoby działania prawej i lewej strony mózgu należy jednak pamiętać, aby nie popaść w zbyt duże uogólnienia. Często przywoływany w publikacjach podział na logicznie myślących „lewopółkulowcow” i działających pod wpływem emocji „prawopółkulowców” jest zdecydowanie bardziej skomplikowany. Sposób opracowania danego materiału zależy przede wszystkim od rodzajów zadań oraz preferencji sposobu ich wykonania w oparciu o wcześniejsze doświadczenia. Aktywność mózgu jest bowiem wynikiem samoregulacji i autoorganizacji oraz szeregu oddziaływań środowiskowych. Dużą rolę w kształtowaniu tych doświadczeń odgrywa stopień aktywizacji prawej i lewej strony mózgu w codziennym życiu. W tym sensie struktura i sposoby przetwarzania języka ojczystego oraz praktyki społeczne mogą rzutować na naukę kolejnych języków, a przyzwyczajenia edukacyjne kształtują sposoby uczenia się. $Z$ tego względu, zastanawiając się nad metodami zdobywania biegłości w języku polskim przez studentów chińskich, należy przyjrzeć się sposobom przetwarzania informacji w języku chińskim mandaryńskim oraz praktykom społecznym i edukacyjnym, które mogły mieć znaczący wpływ na preferencję sposobów uczenia się.

\footnotetext{
${ }^{2}$ Zaburzenia przetwarzania lewopółkulowego są główną przyczyną trudności o charakterze dyslektycznym. Dysleksję cechują trudności w linearnym opracowaniu informacji językowych (w obrębie systemu fonologicznego, morfologicznego, semantycznego i syntaktycznego), którym towarzyszą problemy w linearnym przetwarzaniu informacji symbolicznych, czasowych oraz motorycznych. „Prawopółkulowe przetwarzanie języka jest całkowicie odmienne od lewopółkulowego, oznacza bowiem prymat całościowego rozumienia nad linearnym" (Cieszyńska-Rożek, 2013: 43). Co ciekawe, według danych statystycznych, tylko u 1\% Chińczyków stwierdza się zaburzenia o charakterze dyslektycznym (Stanulewicz 2018, s. 39). Wynikać to może z faktu, że system języka chińskiego rządzi się nieco innymi prawami i w większym stopniu determinuje konieczność zaangażowania prawej półkuli do opracowywania informacji językowych.
} 


\section{SPECYFIKA PRZETWARZANIA JĘZYKA CHIŃSKIEGO}

Język przez swoje związki z poznaniem wpływa na rozwój człowieka, sposób myślenia i zachowania oraz styl poznawczy. W języku zakodowane są bowiem schematy odbioru rzeczywistości i jej opisu oraz sposoby interpretowania zdarzeń. Język chiński różni się znacząco od linearnych zapisów kolejnych dźwięków i wymaga innego rodzaju przetwarzania. Jest językiem tonalnym, w którym intonacja zmienia znaczenie danego wyrazu. Jest to typowa cecha tego języka (ale także wietnamskiego oraz wielu dialektów chińskich), która nie występuje w żadnym z języków europejskich. Istotne jest zatem niezwykle wprawne ucho oraz wrażliwość muzyczna konieczna dla różnicowania dźwięków mowy ze względu na intonację. Odmienności pomiędzy językiem chińskim (w odmianie mandaryńskiej) a językiem polskim ujawniają się w obrębie wszystkich podsystemów.

W zakresie gramatyki zwraca uwagę brak fleksji oraz inny system budowy struktur zdaniowych. W języku chińskim „nic nigdy się nie odmienia: nie ma odmian przez przypadki, osoby, nie ma koniugacji." (Jacoby 2016, s. 69). Nie ma także odmiennej formy dla liczby mnogiej. Jednemu wyrazowi odpowiada zatem jedna niezmienna forma. Niezwykle istotny jest natomiast szyk zdania i kolejność następujących po sobie elementów języka. W języku chińskim wszystkie formy gramatyczne tworzone są w inny sposób - za pomocą partykuł funkcyjnych, które precyzują co, jakim tonem i z jaką konotacją należy wypowiedzieć. Ważną rolę odgrywają także zabiegi rytmiczne (Jacoby 2016, s. 70). Z tego względu system gramatyczny języka polskiego może wydawać się studentom chińskim niezwykle zawiły i skomplikowany. Tym bardziej, że punkt odniesienia stanowi zwykle gramatyka języka angielskiego, w której również nie ma kategorii przypadka, a trudności w odmianie czasowników są niewielkie.

Zasadnicze odmienności są zauważalne w obrębie systemu fonetyczno-fonologicznego. Język chiński (mandaryński) należy bowiem do języków tonalnych, co oznacza, że każda sylaba może być wypowiadana na kilka sposobów. Ze względu na tonalność odbiór i nadawanie komunikatów w języku chińskim wymagają zwiększonej aktywności obszarów korowych znajdujących się w prawej półkuli mózgu, której domeną jest przetwarzanie bodźców muzycznych. Aktywność dodatkowych obszarów po prawej stronie mózgu została potwierdzona w badaniach fMRI (Jianquiao Ge i in. 2015), które wykazały, że użycie języka tonalnego (oprócz ośrodków mowy w półkuli lewej) wymaga także aktywności prawej kory słuchowej. 
Zdjęcie 1. Obszary mózgu aktywne przy przetwarzaniu komunikatów werbalnych przez rodzimych użytkowników języka chińskiego mandaryńskiego oraz języka angielskiego

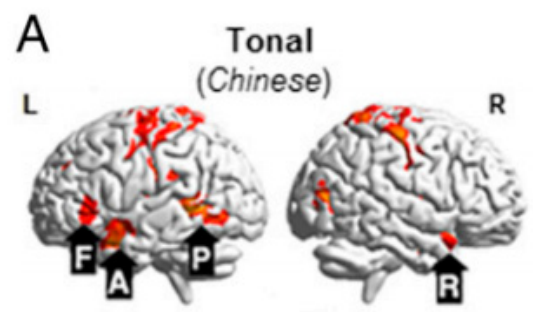

Native Chinese speakers

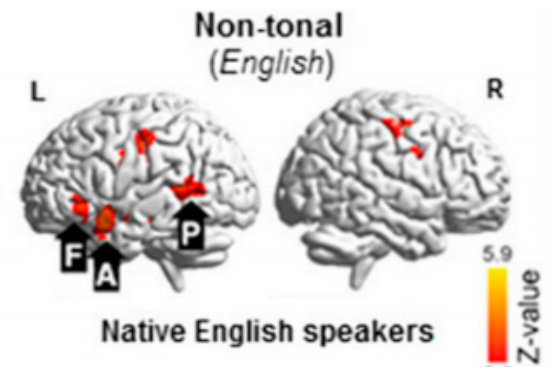

Non-tonal

English

Źródło: Jianqiao Ge i in. 2015, s. 2973

Badania wykazały także, że u użytkowników języka chińskiego proces łączenia dźwięku ze znaczeniem przebiega sprawniej i szybciej niż u rodzimych użytkowników języka angielskiego, co również jest związane z aktywnością prawej półkuli. Co więcej, różnice w modelowaniu aktywności kory mózgowej ujawniają się także podczas posługiwania się znakami chińskimi. Zupełnie odmienny system zapisu wymaga innego rodzaju aktywności w celu ich przetworzenia. Znaków chińskich nie można nazwać alfabetem, ponieważ nie zapisują dźwięków czy wymowy danego słowa, a oddają jego znaczenie, a dokładniej znaczenie jednej sylaby. Wśród znaków chińskich wyróżnia się piktogramy, ideogramy oraz złożenia elementów wymowy, znaczenia, rysunku, idei, skojarzeń oraz klasyfikacji znaczeniowej. Interpretacja znaków wymaga całościowej i symultanicznej analizy (funkcja prawej półkuli) przy jednoczesnej koncentracji na szczegółach (funkcja lewej półkuli). Nie dochodzi tu zatem do działań poddających się wymogom linearności czy przetwarzania sekwencyjnego, jak to ma miejsce w przypadku języków europejskich. Podczas czytania znaków chińskich aktywowane są obszary kory mózgowej, które nie są używane podczas czytania liter. Badania przeprowadzone przez grupę specjalistów (Cao i in., 2013) wykazały wzmożoną aktywność w płacie ciemieniowym i potylicznym w prawej półkuli oraz w korze sensoryczno-motorycznej w półkuli lewej, co świadczy o tym, że proces przetwarzania znaków chińskich aktywizuje dodatkowe obszary prawej strony mózgu. Stwierdzono także, że trening w zakresie pisania znaków chińskich ułatwia dostęp do wzorca leksykalnego i semantyczne dekodowanie znaczenia, powodując większą aktywację w zakrętach środkowo-skroniowych zarówno w półkuli lewej, jak i prawej, podczas gdy trening pisania pinyin (uproszczona transkrypcja znaków chińskich za pomocą alfabetu łacińskiego) ułatwia połączenia $\mathrm{z}$ fonologią poprzez wywoływanie zwiększonej aktywności w prawym płacie czołowym. Nauka chińskich znaków wymaga również wyobraźni przestrzennej - istotne jest bowiem odpowiednie rozmieszczenie elementów. Co więcej, większość znaków to 
złożenia prostszych form, które często zmieniają swoją pierwotną formę. Rozpoznanie ich wymaga działania na zasadzie podobieństwa, co również jest domeną prawej półkuli.

W posługiwaniu się językiem mandaryńskim istotne jest także odniesienie komunikatu do kontekstu i sytuacji aktu mowy. Wynika to z faktu, że , [...] liczba możliwych kombinacji nagłosu i wygłosu w sylabach jest skończona (a więc możliwie istniejących sylab jest stosunkowo niewiele), a większość słów jest krótka - zaledwie jedno- lub dwusylabowa. Oznacza to, że sylab i całych wyrazów, które brzmią zupełnie tak samo, są dziesiątki, a czasem setki." (Jacoby 2016, s. 74). Jako przykład można podać sylabę „shi”, którą można zapisać za pomocą osiemdziesięciu różnych znaków chińskich. Istnieje zatem osiemdziesiąt słów o innym znaczeniu wymawianych niemalże w ten sam sposób (dzięki tonom liczba homofonów ulega zmniejszeniu). O tym, które ze znaczeń użytego słowa jest właściwe, decyduje kontekst. Należy zatem ponownie podkreślić udział procesów prawopółkulowych w komunikacji w języku chińskim, gdyż to prawa kora mózgowa odpowiada za takie działania, jak: odgadywanie znaczenia z kontekstu sytuacyjnego, tworzenie hipotez i interpretacja w oparciu o szereg wskazówek pozajęzykowych ${ }^{3}$.

Ze względu na samą strukturę języka chińskiego należy uznać, że udział prawej półkuli w przetwarzaniu informacji językowych jest większy, a co za tym następuje, u użytkowników języka mandaryńskiego znacznie częściej dochodzi do aktywizacji większych obszarów kory mózgowej w prawej części mózgu niż u rodzimych użytkowników języków nietonalnych, których zapis opiera się na systemach alfabetycznych.

\section{CZYNNIKI KULTUROWE WSPIERAJĄCE ROZWÓJ STRATEGII PRAWOPÓŁKULOWYCH}

Poznawcze oblicze każdego człowieka ma związek z jego cechami społecznymi, które są wynikiem kształtowania się norm i zasad kulturowych. Na styl poznawczy i sposoby zdobywania wiedzy znaczący wpływ mają systemy filozoficzne i religijne, które przejawiają się w codziennych praktykach i zachowaniach. Filozofią, która w dużej mierze ukształtowała sposób myślenia i działania Chińczyków, jest taoizm. Główną wartością taoistyczną, podobnie jak w filozofii

\footnotetext{
${ }^{3}$ Według klasyfikacji stylów komunikacji opracowanej przez E. Halla Chińczycy należą do kultur wysokiego kontekstu. Zgodnie z podanym przez badacza opisem, cechą charakterystyczną komunikacji w kulturach wysokiego kontekstu jest interpretowanie przekazu w oparciu o informacje sugerowane przez kontekst, wysoki udział elementów komunikacji niewerbalnej (mimika, gestykulacja). Istotne są takie elementy, jak: kto, kiedy i w jaki sposób wypowiedział pewne słowa, co pozwala na wyciąganie wniosków, co do znaczenia przekazu (Hall 1976).
} 
konfucjańskiej i buddyjskiej, jest harmonia, która reguluje zasady społecznego współżycia. Zachowanie harmonii wymaga dostosowania się do zmieniających się okoliczności i sprzeczności, które leżą w naturze świata. Ich akceptacja i przekonanie, że aby zrozumieć jeden stan rzeczy, musi zaistnieć jego przeciwieństwo, stanowi fundament myśli taoistycznej (Kohn 2012). Wyraża to symbolicznie figura yin-yang, w której pierwiastki ciemny i jasny (przedstawiające różnego rodzaju przeciwieństwa) wzajemnie się uzupełniają. „Chińczycy wierzą, że wszystko nieustannie się zmienia, ale zawsze wraca do wcześniejszego stanu. Patrzą na wiele zdarzeń równocześnie, szukając zależności miedzy rzeczami i uważają, że niemożliwe jest zrozumienie części bez zrozumienia całości." (Nisbett 2015, s. 11). Ważniejsze zatem jest holistyczne pojmowanie zjawisk niż analiza poszczególnych ich elementów, a akceptacja takiego stanu rzeczy istotniejsza jest niż jego zrozumienie.

Odkrywanie zasad rządzących obiektami i próby zrozumienia wszechświata poprzez opis poszczególnych jego elementów jest bardziej typowe dla przedstawicieli kultury Zachodu. Już starożytni Grecy poszukiwali odpowiedzi na fundamentalne pytania dotyczące natury świata poprzez zadawanie pytań i formułowanie odpowiedzi na drodze dedukcji. Starożytni Chińczycy koncentrowali się natomiast nie tyle na poszukiwaniu jednego właściwego sposobu działania w oparciu o logiczną argumentację, co na akceptacji przeciwieństw i patrzeniu na świat jako harmonię przeciwieństw. Filozofia paradoksu wpisana jest w sposób poznawania i interpretowania zjawisk i zdarzeń. P. Boski różnice pomiędzy zachodnim i wschodnim systemem poznawania świata opisuje następująco: „Euroamerykańskiemu zamiłowaniu do logicznej argumentacji i uwrażliwieniu na sprzeczność odpowiada dalekowschodnia akceptacja współobecności sprzecznych elementów, zależnych od kontekstu prawd cząstkowych, drogi środka między nimi i afirmacja paradoksalnej natury rzeczywistości." (Boski 2010, s. 343). Myślenie logiczne, oparte na argumentowaniu i analizie konkretnych przesłanek, stanowi domenę lewej półkuli, a myślenie holistyczne, syntetyzujące różne elementy w jedną całość jest aktywnością typową dla prawej części mózgu. Praktyki społeczne, które powstały na gruncie taoizmu i, opartej na jego przesłankach, filozofii konfucjańskiej w większym stopniu będą kształtowały style poznawcze wspierające aktywność prawej półkuli i przez nią wspierane.

System edukacji i styl nauczania mogą determinować wybór strategii prawobądź lewopółkulowych. Okres edukacji szkolnej to kilkanaście lat kształtowania nie tylko wiedzy, ale również sposobów jej zdobywania i wykorzystywania. Ciekawym przykładem jest zestawienie dwóch modeli kształcenia dokonane przez P. Boskiego, który porównuje dominujący w Europie i szeroko pojętej kulturze Zachodu model sokratejski z nauczaniem w duchu konfucjańskim - obowiązującym w Chinach. Różnice te można rozpatrywać na kilku płaszczyznach: treści (czego głównie się naucza: solidnej wiedzy czy myślenia o problemach), wymagań 
(czego oczekuje się od uczniów: pracowitości i pamięciowego opanowania materiału czy umiejętności dedukcyjnych, zdolności rozwiązywania problemów i kreatywnego myślenia) oraz roli nauczyciela (czy powinien być niedościgłym mistrzem czy przewodnikiem w samodzielnym odkrywaniu wiedzy). W systemie sokratejskim podstawowym założeniem jest dochodzenie do wiedzy na podstawie dialogu, umiejętność wnioskowania z danych przesłanek i działania dedukcyjne. W tym ujęciu nauczyciel pełni rolę doradcy, przewodnika, który pomaga odkryć swoim uczniom nowe prawdy. Kultura Zachodu kultywuje myślenie krytyczne, indywidualizm i racjonalne dochodzenie do wiedzy. Taki sposób myślenia i działania łatwiej jest także ująć w słowa, opowiedzieć krok po kroku, ze względu na jego linearny charakter. Oparty na wnioskowaniu proces uczenia się bardziej angażuje lewą półkulę mózgu i przyczynia się do kształtowania lewopółkulowych strategii przyswajania wiedzy.

Zupełnie inaczej rzecz ma się w przypadku edukacji konfucjańskiej, według której myślenie krytyczne prowadzi do chaosu, a zatem najistotniejsze jest przyswojenie sobie solidnej wiedzy płynącej od nauczyciela uznawanego za mistrza. Wiedza opanowywana jest głównie pamięciowo jako konkretne dane oparte na solidnych fundamentach (Boski 2010, s. 363). Uczniowie w chińskich szkołach przyswajają pamięciowo reguły, wspólnie recytują wiersze i wyuczone czytanki. Takim metodom kształcenia sprzyja, i jednocześnie je wymusza, sposób organizacji szkół. Dzieci od wczesnych lat spędzają w placówkach edukacyjnych dużo czasu. Klasy są bardzo liczne - w mniejszych szkołach mogą liczyć ok. 30 uczniów, ale liczba ta może dochodzić nawet do 60 osób. Trudno wyobrazić sobie pedagogikę nastawioną na wykonywanie wspólnych zadań czy odkrywanie relacji pomiędzy zjawiskami w tak licznej grupie. Nie ma tu także zbyt wiele przestrzeni dla, tak cenionego przez Zachód, indywidualizmu. Dzieci uczą się razem. Edukacja prowadzona $\mathrm{w}$ ten sposób sprzyja stosowaniu strategii prawopółkulowych (wspólne rytmiczne recytacje, nauka całych tekstów, śpiewanie piosenek, zwyczaj wspólnego porannego czytania tekstów literackich) (Afek, Gut 2017).

Bardzo ciekawe jest także odmienne podejście do kwestii pojmowania inteligencji i sposobów jej mierzenia. Testy inteligencji, które w cywilizacji zachodniej stosowane są do pomiaru ogólnej sprawności umysłowej od ponad stu lat, w kulturze chińskiej używane były już ponad 1000 lat temu. Ich analiza pokazuje, że samo pojęcie inteligencji czy sprawności kognitywnej ujmuje się w obu kulturach zupełnie odmiennie (Nisbett, 2010). W ogólnie stosowanych testach (np. wystandaryzowanych skalach Wechslera) często pojawiają się zadania wymagające analizy relacji, wnioskowania dedukcyjnego oraz analitycznego sposobu myślenia, a w testach chińskich częściej spotkamy się z zadaniami wymagającymi globalnego przetwarzania problemu, które czasami trudno jest racjonalnie wyjaśnić. W większym stopniu wykorzystuje się zatem myślenie globalne i przetwarzanie całościowe, za które odpowiada półkula prawa. Holistyczny sposób rozwiazywa- 
nia problemów wymyka się linearnemu przetwarzaniu, czego dowodzą wyniki badań przeprowadzonych na gruncie psychologii międzykulturowej (Norenzayan, Smith, Kim, Nisbett 2002). Zgodnie z opisem badaczy przedstawiciele krajów Dalekiego Wschodu przetwarzają problemy całościowo i podają rozwiązanie. Nie potrafią jednak przedstawić krok po kroku swojego toku myślenia. W większym stopniu odwołują się także do znaczenia kontekstu i wcześniejszych doświadczeń niż do danych leżących u podstaw konkretnego zadania Wszystkie te operacje są typowe dla przetwarzania prawopółkulowego.

\section{BADANIA SONDAŻOWE I PERSPEKTYWY BADAWCZE}

Odniesienie charakterystyki działania prawej i lewej półkuli do wiedzy na temat wybranych aspektów kulturowych, które są typowe dla społeczeństwa chińskiego oraz obserwacja sposobu uczenia się języka polskiego przez studentów chińskich skłaniają do przyjęcia hipotezy o preferowaniu przez nich działań aktywizujących prawą półkulę w procesie zdobywania informacji. Dla weryfikacji tej hipotezy przeprowadzono sondaż wśród studentów chińskich na temat wybieranych przez nich sposobów uczenia się. W rozmowach wzięło udział 22 studentów uczących się na kierunku Studia polskie oraz 16 uczestników rocznych lub semestralnych kursów języka i kultury polskiej w Instytucie Glottodydaktyki Polonistycznej w UJ - łącznie 38 studentów z Chin. Pytania dotyczyły sposobów opanowywania podsystemów, rozwijania sprawności językowych oraz identyfikowanych trudności w opanowywaniu materiału. Wśród sposobów najczęściej wymienianych przez studentów znalazły się następujące techniki:

- uczenie się oparte na zapamiętywaniu całych fraz, zdań, krótkich tekstów;

- wielokrotne odsłuchiwanie i powtarzanie materiałów audio;

- nauka przez słuchanie piosenek;

- przedkładanie solidnego komentarza gramatycznego i instrukcji nad zadania oparte na wnioskowaniu i indukcji;

- konieczność automatyzowania form gramatycznych poprzez wykonywanie schematycznych ćwiczeń;

- odgrywanie dialogów i scenek (najchętniej według dostarczonego schematu);

- $\quad$ praca w parach lub w grupach;

- rozumienie z kontekstu i konsytuacji;

- wizualizacja treści.

Wymieniane przez badanych sposoby uczenia się potwierdzają zasadność hipotezy o wyższym udziale prawej półkuli w procesie zdobywania i przetwarzania informacji o charakterze językowym. Co ciekawe, studenci podkreślają, że 
w początkowych fazach nauki niechętnie angażowali się w dyskusje i rzadko wyrażali swoją opinię na forum grupy. Studenci uczący się w grupach mieszanych narodowościowo w dalszym ciągu odczuwają pewnego rodzaju trudność, gdy oczekuje się od nich wypowiedzi polemicznej wobec opinii koleżanek lub kolegów.

Badania nad potencjałem półkul mózgowych są coraz częściej podejmowane przez specjalistów z zakresu nauk medycznych i psychologów we współpracy z dydaktykami i metodykami, a ich wyniki prowadzą do ciekawych wniosków. Opisane w niniejszym artykule badania mają charakter wstępny. Ich podstawowym celem było sprawdzenie, czy przedstawioną hipotezę można uznać za godną uwagi. Wyniki wywiadów sondażowych potwierdzają, że warto kontynuować badania w tym kierunku. Przedstawiony w niniejszym artykule opis złożoności języka chińskiego i podstaw regulujących życie codzienne, choć bardzo ogólny i uproszczony, wskazuje na to, że kultura i wychowanie modelują sposoby przetwarzania danych językowych, co nie pozostaje bez znaczenia podczas nauki. Zasadne zatem jest zaplanowanie szczegółowych badań o charakterze interdyscyplinarnym (np. z wykorzystaniem funkcjonalnego rezonansu magnetycznego pokazującego aktywność określonych części kory mózgowej podczas wykonywania różnego typu ćwiczeń i zadań językowych), które pozwoliłyby na rzetelną weryfikację przedstawionej hipotezy. Niniejsze badania, ze względu na przyjętą metodologię (wywiad i obserwacja uczestnicząca) i ograniczenia, mogą stanowić jedynie istotny argument dla rozpoczęcia szerzej zakrojonych badań specjalistycznych.

\section{BIBLIOGRAFIA}

Afek J., Gut A., 2017, O chińskim modelu wczesnej edukacji dziecięcej w kontekście międzykulturowych badań psychologicznych, „Roczniki Humanistyczne”, nr 65(9), s. 5-28. DOI 10.18290/ rh.2017.65.9-1

Berko Gleason J., Bernstein Ratner N., 2005, Psycholingwistyka, Gdańsk.

Boski P., 2010, Kulturowe ramy zachowań społecznych. Podręcznik psychologii międzykulturowej, Warszawa.

Budohoska W., Grabowska A., 1994, Dwie pótkule - jeden mózg, Warszawa.

Cao F., Vu M., Chan D.H.L., Lawrence J.M., Harris L.N., Guan Q., Xu Y., Perfetti C.A., 2013, Writing affects the brain network of reading in Chinese: A functional magnetic resonance imaging study. „Human Brain Mapping”, 34 (7), s. 1670-1684. DOI: 10.1002/hbm.22017

Cieszyńska-Rożek J., 2013, Metoda krakowska wobec zaburzeń rozwoju dzieci. Z perspektywy fenomenologii, neurobiologii i językoznawstwa, Kraków.

Durham W., 1991, Coevolution - genes, culture, and human diversity, Stanford.

Gazzaniga M.S., 2011, Istota człowieczeństwa. Co sprawia, ze jesteśmy wyjątkowi, Sopot.

Grabowska A., 2012, Lateralizacja funkcji psychicznych w mózgu człowieka, w: T. Górska, A. Grabowska, J. Zagrodzka (red.), Mózg a zachowanie, Warszawa, s. 443 - 488.

Hall E., 1976/2001, Poza kultura, Warszawa.

Jacoby M., 2016, Chiny bez makijażu, Warszawa. 
Jianquiao G., Gang P., Bingjiang L., Yi W., Yan Z., Zhendong N. i in., 2015, Cross-language differences in the brain network subserving intelligible speech, Proceedings National Academy of Sciences of the USA, t. 112: 10, s. 2972-2977. DOI: 10.1073/pnas. 1416000112

Kohn L., 2012, Taoizm. Wprowadzenie, Kraków.

Markus H., Kitayama S., 1993, Kultura i ja. Implikacje dla celów poznawczych, emocji i motywacji, „Nowiny Psychologiczne, nr 3, s. 5-70.

Matsumoto D., Juang 1., 2007, Psychologia międzykulturowa, Gdańsk.

Nisbett R.E., 2010, Inteligencja. Sposoby oddziaływania na IQ, Sopot.

Nisbett R.E., 2015, Geografia myślenia. Dlaczego ludzie Wschodu i Zachodu myśla inaczej?, Sopot.

Nisbett R.E., Peng K., Choi I., Norenzayan A., 2001, Culture and systems of thought: Holistic versus analytic cognition, „Psychological Review”, nr 108, s. 291-310. DOI: 10.1037/0033$295 x .108 .2 .291$

Norenzayan A., Smith E., Kim B.J, Nisbett R.E., 2002, Cultural preferences for formal versus intuitive reasoning, „Cognitive Science”, nr 26, s. 653-684. DOI 10.1016/S0364-0213(02)00082-4

Panasiuk J., 2017, Neurobiologiczne podstawy mowy, w: S. Milewski, J. Kuczkowski, K. Kaczorowska-Bray (red.), Biomedyczne podstawy logopedii, Gdańsk, s. 359-409.

Stanulewicz D., 2018, Język a kultura i środowisko, w: E. Czaplewska (red.), Logopedia międzykulturowa, Gdańsk, s. 26-39.

Szeląg E., 2012, Mózgowe mechanizmy mowy, w: T. Górska, A. Grabowska, J. Zagrodzka (red.), Mózg a zachowanie, Warszawa, s. 489-524.

Tomasello M., 2002, Kulturowe źródła ludzkiego poznawania, Warszawa.

Adriana Prizel-Kania

\section{THE NEUROBIOLOGICAL AND CULTURAL ASPECTS OF THE WAYS OF ACQUIRING AND PROCESSING INFORMATION, AS EXEMPLIFIED BY CHINESE STUDENTS LEARNING POLISH AS A FOREIGN LANGUAGE}

Keywords: Polish as a foreign language, Chinese, cultural aspects, learning patterns, right-brained strategies

Summary. The subject of the article is the influence of neurobiological and cultural factors on the ways of acquiring and processing information, which in turn determine the choice of learning methods. The paper discusses the issue of hemispherical preferences in the educational context. The starting point of the research is the thesis that individuals using Mandarin as their native tongue and raised in the Chinese culture prefer those ways of acquiring knowledge which activate the right cerebral hemisphere. The research presents the results of observations and interviews held with students from China who have been learning Polish as a foreign language, about the learning methods and techniques that they use. The research conclusions have been interpreted on the basis of the cultural factors (native tongue and social practices) that are particularly conducive to choosing right-hemisphere strategies in the learning process. 
